\title{
UNIVERSITYOF BIRMINGHAM

\section{The Sons of Aaron in the Dead Sea Scrolls}

\author{
Hempel, Charlotte; Hilhorst, A; Puech, E; Tigchelaar, E
}

Citation for published version (Harvard):

Hempel, C, Hilhorst, A, Puech, E \& Tigchelaar, E 2007, The Sons of Aaron in the Dead Sea Scrolls. in Flores

Florentino. Dead Sea Scrolls and Other Early Jewish Studies in Honour of Florentino Garcia Martinez/

Supplements to the Journal for the Study of Judaism, 122.

Link to publication on Research at Birmingham portal

\section{General rights}

Unless a licence is specified above, all rights (including copyright and moral rights) in this document are retained by the authors and/or the copyright holders. The express permission of the copyright holder must be obtained for any use of this material other than for purposes permitted by law.

- Users may freely distribute the URL that is used to identify this publication.

- Users may download and/or print one copy of the publication from the University of Birmingham research portal for the purpose of private study or non-commercial research.

- User may use extracts from the document in line with the concept of 'fair dealing' under the Copyright, Designs and Patents Act 1988 (?)

-Users may not further distribute the material nor use it for the purposes of commercial gain.

Where a licence is displayed above, please note the terms and conditions of the licence govern your use of this document.

When citing, please reference the published version.

Take down policy

While the University of Birmingham exercises care and attention in making items available there are rare occasions when an item has been uploaded in error or has been deemed to be commercially or otherwise sensitive.

If you believe that this is the case for this document, please contact UBIRA@lists.bham.ac.uk providing details and we will remove access to the work immediately and investigate. 


\section{The Sons of Aaron in the Dead Sea Scrolls*}

The evidence of the Dead Sea Scrolls on the priestly designations 'sons of Aaron' and 'sons of Zadok' is one of the areas where the more recently published texts have provided scholars with a significant amount of additional evidence. One thinks here, for instance, of the important textual variants between $1 \mathrm{QS} 5$ and $4 \mathrm{Q} S^{\mathrm{d}}$ I and $4 \mathrm{Q} \mathrm{S}^{\mathrm{b}}$ IX. ${ }^{1}$ The topic of the priesthood as depicted in the non-biblical scrolls has been one that has been the subject of a number of studies since the earliest decades after the

\footnotetext{
${ }^{*}$ It is a great privilege to publish these thoughts in a Festschrift for Florentino García Martínez. Ever since I first read his work as a senior undergraduate I was profoundly impressed and influenced by his scholarship. I first met Florentino at the Meeting of the International Organization of Qumran Studies in Cambridge in 1995. Ever since I have benefited tremendously from Florentinos boundless generosity, energy and efficiency. He has done a tremendous amount for the discipline, and his hard and selfless labour has paved a much smoother path for my own generation of scholars. I should also like to thank Menahem Kister. I benefited greatly from an informal discussion while writing this paper.

${ }^{1}$ See, e.g., G. Vermes, "Preliminary Remarks on Unpublished Fragments of the Community Rule from Qumran Cave 4,” JJS 42 (1991): 250-255; P. S. Alexander, “The Redaction-History of Serekh haYahad: A Proposal,” RQ 17 (1996): 437-453; A. I. Baumgarten, “The Zadokite Priests at Qumran: A Reconsideration,” DSD 4 (1997): 137-156; M. Bockmuehl, "Redaction and Ideology in the Rule of the Community (1QS/4QS):,” RQ 18 (1998): 541-560; J. H. Charlesworth and B. A. Strawn, "Reflections on the Text of Serek ha-Yaad Found in Cave IV,” RQ 17 (1996): 403-435; P. Garnet, "Cave 4 MS Parallels to 1QS 5:1-7: Towards a Serek Text History,” JSP 15 (1997): 67-78; C. Hempel, “Comments on the Translation of 4QSd I,1,” JJS 44 (1993):127-128; and M. A. Knibb, "Rule of the Community," Encyclopedia of the Dead Sea Scrolls (ed. L. H. Schiffman and J. C. VanderKam; New York: Oxford University Press, 2000), II, 793-797 and S. Metso, The Textual Development of the Qumran Community Rule (STDJ 21; Leiden: Brill, 1997).
} 
discovery, and has been lavished with even more attention in the last two decades. ${ }^{2}$ In what follows I would like to look particularly at the evidence of the scrolls on the sons of Aaron. My impression is that both in some of the primary sources as well as in the secondary literature the sons of Aaron have suffered under the dominant place allotted to the sons of Zadok in a number of places. ${ }^{3}$ This situation is recognized also by G. Vermes when he regretfully observes the way in which "the terminological clash between sons of Zadok and sons of Aaron largely remained untouched for some four decades of Qumran research during which period most scholars [...] happily and simply maintained, without any proviso, that the sect was governed by the sons of Zadok the priests...”. $\mathrm{I}$ have always been puzzled by the awkward coexistence of both designations in the Rule texts. ${ }^{5}$ I was inspired to reflect more closely on the

${ }^{2}$ For an excellent concise overview with ample bibliography see R. A. Kugler, "Priests", in Encyclopedia of the Dead Sea Scrolls (ed. Schiffman and VanderKam), II, 688-693. See also idem, “Priesthood at Qumran”, in The Dead Sea Scrolls After Fifty Years. A Comprehensive Assessment (ed. P. Flint and J. C. VanderKam; Leiden: Brill, 1999), II, 93-116. See also G. Vermes, “The Leadership of the Qumran Community: Sons of Zadok - Priests - Congregation”, in Geschichte-Tradition-Reflexion. Festschrift für Martin Hengel zum 70. Geburtstag (ed. H. Cancik, H. Lichtenberger, and P. Schäfer; Tübingen: Mohr Siebeck, 1996), I, 375-384.

${ }^{3}$ See, e.g., the seminal article by J. Liver, “The 'Sons of Zadok the Priests' in the Dead Sea Sect”, $R Q$ 6 (1967): 3-30. For a different point of view see P. R. Davies, Behind the Essenes. History and Ideology in the Dead Sea Scrolls (BJS 94; Atlanta: Scholars Press, 1987), 51-72 where he concludes “Scholars of Qumran simply must stop talking Zadokite.,” 71 and already G. Klinzing, Die Umdeutung des Kultus in der Qumrangemeinde und im Neuen Testament (StUNT 7; Göttingen: Vandenhoeck\&Ruprecht, 1971), 136.

4 “Leadership of the Qumran Community”, 379.

${ }^{5}$ See, e.g., C. Hempel, “The Earthly Essene Nucleus of 1QSa”, DSD 3 (1996): 253-269; eadem, “Interpretative Authority in the Community Rule Tradition”, DSD 10 (2003): 59-80, and most recently eadem, “The Literary Development of the S-Tradition. A New Paradigm”, RQ 22 (2006): 389-401, esp. 
picture that emerges about the somewhat elusive Aaronides by the excellent recent article by H.-J. Fabry, “Zadokiden und Aaroniden in Qumran”. ${ }^{6}$ There Fabry offers an overview over and analysis of the complex evidence on the priesthood as it emerges from various strands in the Hebrew Bible such as the Deuteronomistic History, the Priestly work, the Book of Ezekiel, the Chronicler to the Greek Bible, Ben Sira and Qumran. With reference to the scrolls he rightly emphasizes the way in which references to the sons of Aaron the priests vastly outnumber references to the sons of Zadok the priests. ${ }^{7}$ I agree with a great deal of what he has to say but wish to add some further nuances to this ongoing debate. In particular this article is intended to respectfully contradict his conviction that, "Die Regelliteratur lässt uns keine inhaltlichen und konzeptionellen Unterschiede [with respect to Aaronides and Zadokites] mehr wahrnehem.” ${ }^{8}$ In what follows I will argue that despite the fact that both traditions co-exist in some sources, we are in a position to trace a trajectory of development in the rule texts and beyond. The topic of this investigation seems a fitting one in a Festschrift for Florentino García Martínez who has written on the

395-397. See already Liver, "Sons of Zadok the Priests”, 13 where he notes, "The selfsame texts in the Rule Scroll, wherein mention is made of "the sons of Zadok the priests”, contain parallel references to "the sons of Aaron the priests" or to the priests in general."

${ }^{6}$ H.-J. Fabry, “Zadokiden und Aaroniden in Qumran”, in Das Manna fällt auch heute noch. Beiträge zur Geschichte und Theologie des Alten, Ersten Testaments. FS E. Zenger (ed. F.-L. Hossfeld and L. Schwienhosrt-Schönberger; Freiburg: Herder, 2004), 201-217.

7 “Zadokiden und Aaroniden”, 209.

8 “Zadokiden und Aaroniden”, 213. He continues by granting that such differences “müssen aber bestanden haben” on the basis of the terminology in messianic contexts, ibidem. 
ways in which the priests in the Qumran community continued to undertake priestly functions in a community that did not participate in the temple cult. ${ }^{9}$

In order to form as full a picture as possible, I have considered all the references to the sons of Aaron and the sons of Zadok in the scrolls. Before looking at the evidence, it is worth noting that I have left out of consideration the references to a priest or priests that do not supply a reference to their genealogical descent. I have argued elsewhere recently that a number of passages that speak of incipient communal life in a smallscale context lack concern for the genealogical descent of the priest(s), i.e. 1QS 6:2-4 and $1 \mathrm{QS}$ 8:1. ${ }^{10}$ Both of these passages share with some of the material discussed below an emphasis on priestly authority in the community without any expressed concerns for the kind of priest required.

Finally, a number of scholars have argued - frequently in the days before the complex evidence of the 4QS manuscripts had become available - that there is no issue to debate since 'sons of Zadok' and 'sons of Aaron' are simply synonyms for one and the same entity. ${ }^{11}$ This view seems unlikely to me. As we will see, the full range of

\footnotetext{
${ }^{9}$ F. García Martínez, "Priestly Functions in a Community Without Temple”, in Gemeinde ohne Temple (ed. B. Ego, A. Lange and P. Pilhofer; WUNT 118; Tübingen: Mohr Siebeck, 1999), 303-319.

10 “Diversity and Identity in the S Tradition”, in Defining Identities. We, You, and the Others in the Dead Sea Scrolls (ed. F. Garcia Martinez; Leiden: Brill), forthcoming.

${ }^{11}$ See, e.g., G. A. Anderson, “Aaron”, in Encyclopedia of the Dead Sea Scrolls (ed. Schiffman and VanderKam), I, 1-2; Klinzing, Umdeutung des Kultus, 135f.; M. A. Knibb, The Qumran Community (Cambridge Commentaries on Writings of the Jewish and Christian World 200 BC to AD 200 2; Cambirdge: CUP, 1987), 105; A. R. C. Leaney, The Rule of Qumran and Its Meaning (NTL; London: SCM), 177 who comments with reference to $1 \mathrm{QS}$ 5:22, "Sons of Aaron is no more than a variant for
} 
passages also indicates that there are contexts in which only one of the two sets of terms are employed which points towards a subtle difference in the use of the terminology. ${ }^{12}$ In what follows I hope to draw up a profile of the occurrences of both sets of terms.

\section{The Damascus Document}

The Admonition of this text never refers to the sons of Aaron. Noteworthy, however, are repeated references to the people as a whole in terms of 'Aaron and Israel' both in contexts describing communal origins (cf. CD 1:7 // 4Q266 2 i 11 // 4Q268 1:14; CD 6:2 // 4Q267 2:8) as well as in eschatological contexts that refer to a Messiah of Aaron and Israel (cf. CD 19:11; 20:1).

References to the expectation of a Messiah of Aaron and Israel are also interspersed in the legal part of the Damascus Document, cf. CD 12:23; CD 14:19 // 4Q266 10 i 12 // 4Q269 11 i 2. However, unlike the Admonition the legal part of the Damascus Document contains six references to the sons of Aaron including one in the catalogue of transgressions. Of these, four references are preserved in the material dealing with the disqualification of certain categories of priests.

a. 4Q266 5 ii 5 // 4Q267 5 iii 8

'[one] of the sons of Aaron who is taken captive by the nations'

sons of Zadok here.” Further, G. Vermes in E. Schürer, The History of the Jewish People in the Age of Jesus Christ (Rev. ed. G. Vermes, F. Millar, and M. Black; Edinburgh: T\&T Clark, 1979), II, 252-253 n. 56.

${ }^{12}$ Note also the point made by Fabry, namely, that we would expect a more evenly distributed number of references to each designation if their employment was more or less random in the scrolls, see “Zadokiden und Aaroniden”, 209. 
b. 4 Q266 5 ii 8

'one of the sons of Aaron who departs to ser[ve the nations'

c. $4 \mathrm{Q} 2665$ ii $9-10$

'[one of the sons of] Aaron who causes his name to fall from the truth (corrected to: whose name was thrown from the peoples), 13

d. 4Q266 5 ii 12

'from Israel, the counsel ${ }^{14}$ of the sons of Aaron

Two further references to the sons of Aaron occur in the Laws. One spells out the responsibility of the sons of Aaron to diagnose skin disease, cf. 4Q266 6 i 13 // 4Q272 1 ii $2 .^{15}$ All indicates that sometimes sons of Aaron or Aaron is nothing more than priestly versus lay - Menahem point but he thought across the board. Finally, the catalogue of transgressions lists someone who fails to '[give to] the sons of Aaron [the fourth (year)] planting,' cf. 4Q270 2 ii 6. Although part of this statement is

\footnotetext{
${ }^{13}$ The text appears to be corrected from “fallen from the truth” to "was thrown from the peoples”, cf. J. M. Baumgarten, Qumran Cave 4. XIII. The Damascus Document (4Q266-273) (DJD 18; Oxford: Clarendon, 1996), 51. The latter would correspond more closely with the interest of this passage in gentiles. By contrast, the reference to someone who has diverted from the truth has a more restricted ring to it and is reminiscent of the penal code as noted by Baumgarten, Qumran Cave 4. XIII, 51.

${ }^{14}$ The term counsel/council is interesting since it is a key term in the Community Rule where is describes one of the central elements of fellowship of community members. However, the reference to "Israel" immediately before the reference to the sons of Aaron seems to indicate that we are still in a national context of Israel and the nations as in a number of earlier references. On this issue see also García Martínez, "Priestly Functions”, 314-315. In contrast to the emphasis placed here, García Martínez examines these laws against a community-internal rather than national backdrop.

15 We may compare this to CD 13:4-7a which clarifies that it is a priestly duty to diagnose skin disease, even if the priest is a simpleton and needs help and advice from the overseer.
} 
reconstructed, the preserved text in the lines that follow leaves little doubt that this part of the catalogue deals with priestly dues. ${ }^{16}$

In sum, the Laws of the Damascus Document frequently refer to the sons of Aaron in contexts that are not community specific. The national context (Israel and the nations) is repeatedly in focus in the material on priestly disqualifications. Moreover, the catalogue of transgressions and the skin disease material both employ sons of Aaron terminology to refer to traditional priestly duties and privileges rather than as figures of authority in a particular community.

The sons of Aaron play no role in the Admonition, as we saw. However, the Damascus Document does contain a reference to 'the so]ns of Zadok the priests' (4Q266 5 i 16) in an intriguing passage that includes material reminiscent both of the Admonition and the Laws (4Q266 5 i /4Q267 5 ii). ${ }^{17}$ By combining references to the 'returnees/penitents of Israel' with references to 'the sons of Zadok' the former passage is reminiscent of CD 3:20c-4:4a, which comprises a quoatation and interpretation of Ezek 44:15 applying it to three phases in the reform movement's development. In the latter well-known passage the sons of Zadok are identified as the elect of Israel at the end of days. It is the 'sons of Zadok' terminology found here in the Admonition that gave rise to the document's earlier title Fragments of a Zadokite

\footnotetext{
${ }^{16}$ See Baumgarten, Qumran Cave 4. XIII, 142-146 and C. Hempel, The Damascus Texts (Companion to the Qumran Scrolls 1; Sheffield: Sheffield Academic Press), 2000, 33-34, 42-43, 87-88 and further literature referred to there.

17 See Baumgarten, Qumran Cave 4. XIII, 4-5; 47-49; C. Hempel, The Laws of the Damascus Document. Sources, Traditions and Redaction (STDJ 29; Leiden: Brill), 1998, 171-174; eadem, Damascus Texts, 34.
} 
Work. ${ }^{18}$ In any case, it seems clear that both in the 'mixed passage' in 4Q266 $5 \mathrm{i}$ and in the Admonition 'sons of Zadok' is the preferred terminology. Noteworthy, moreover, is the community specific background of both references. In the 'mixed passage' the references to the overseer and the maskil in nearby lines make this clear. In CD 3-4 'sons of Zadok' refers not to the priests, in particular, but apparently to the community as a whole. ${ }^{19}$ In short, it seems to me quite clear, that we may observe a distinctive use of the terminology 'sons of Aaron' in the Damascus Document, namely in non-community-specific contexts with reference to traditional priestly duties and rights.

\section{The Community Rule}

Before turning to references to the sons of Aaron, it is worth noting that not unlike the Damascus Document, the Community Rule also refers to the make-up of the community in the present and the future in terms of Aaron and Israel, cf. 1QS 5:6 // 4QS ${ }^{\mathrm{b}} \mathrm{IX}: 5-6 / / 4 \mathrm{QS}^{\mathrm{d}}$ I:5 and 1QS 8:6 // 4QS ${ }^{\mathrm{e}}$ (4Q259) II:14; 1QS 8:8-9 // 4QS ${ }^{\mathrm{d}}$ VI:2-3 // 4QS ${ }^{\mathrm{e}}$ II: 17-18; 1QS 9:5-6 // 4QS ${ }^{\mathrm{d}}$ VII:6-7. Again very reminiscent of the picture painted in the Damascus Document, 1QS 9:11 - but not 4QS ${ }^{\mathrm{e}}$ - includes a reference to the expectation of 'a prophet and messiahs of Aaron and Israel'. Of particular interest for the present enquiry are two places in the Community Rule manuscripts where the sons of Aaron are assigned the role of leading authority figures in the community.

\footnotetext{
${ }^{18}$ Solomon Schechter, Documents of Jewish Sectaries. I. Fragments of a Zadokite Work (Cambridge: CUP, 1910). The earlier title is favourably recalled by Baumgarten, Qumran Cave 4. XIII, 1. For a more recent treatment see M. L. Grossman, Reading for History in the Damascus Document. A Methodological Study (STDJ 45; Leiden: Brill, 2002), 185-209.

${ }^{19}$ Cf. Liver, “Sons of Zadok the Priests”, 10.
} 
The first passage is found in 1QS 5:21 // $4 Q^{\mathrm{d}}$ (4Q258) II: 1-2

\begin{tabular}{|c|c|}
\hline $\begin{array}{l}\text { 1QS } \\
\text { 'according to the authority of the sons of } \\
\text { Aaron (...) and }{ }^{20} \text { the authority of the } \\
\text { multitude of Israel' }\end{array}$ & $\begin{array}{l}4 \mathrm{QS}^{\mathrm{d}} \\
\text { 'according to the authority of the sons of } \\
\text { Aaron (...) the authority of the multitude } \\
\text { of Israel.' }\end{array}$ \\
\hline
\end{tabular}

The common ground between $1 \mathrm{QS}$ and $4 \mathrm{QS}^{\mathrm{d}}$ in this particular passage is extremely interesting since it contrasts sharply with the much more widely discussed instance in 1QS $5 / / 4 Q^{d}$ where both manuscripts differ sharply in their authority structure. I have recently drawn attention to the immense significance of the shared tradition in 1QS 5:21 // 4QS ${ }^{\mathrm{d}}$ II: 1-2 and elsewhere in the S manuscripts. ${ }^{21}$ It seems to me that the earliest elements in the growth of the $\mathrm{S}$ tradition are to be found in the common ground between the manuscripts allowing us glimpses of the state of affairs before the manuscripts went their separate ways, so to speak. What is significant for the current enquiry is the presence in the S tradition - and if I am correct in the earliest strands of the S tradition - of an endorsement of the sons of Aaron's leading role in the community. This tradition differs from the strong endorsement of the sons of Zadok in other parts of S, esp. 1QS 5.

A similar picture emerges from the second passage I wish to focus on, namely 1QS 9:7 // 4QS ${ }^{\mathrm{d}}$ (4Q258) VII:7 which contains a further endorsement of the authoritative role of the sons of Aaron in both $1 \mathrm{QS}$ and $4 \mathrm{QS}^{\mathrm{d}}$.

\footnotetext{
${ }^{20}$ The absence of the conjunction in $4 \mathrm{QS}{ }^{\mathrm{d}}$ may be significant, cf. Hempel, "Interpretative Authority”, 76-79.

21 “The Literary Development of the S-Tradition”.
} 
1QS 9:7 // 4QS ${ }^{\mathrm{d}}(4 \mathrm{Q} 258) \mathrm{VII}: 7^{22}$

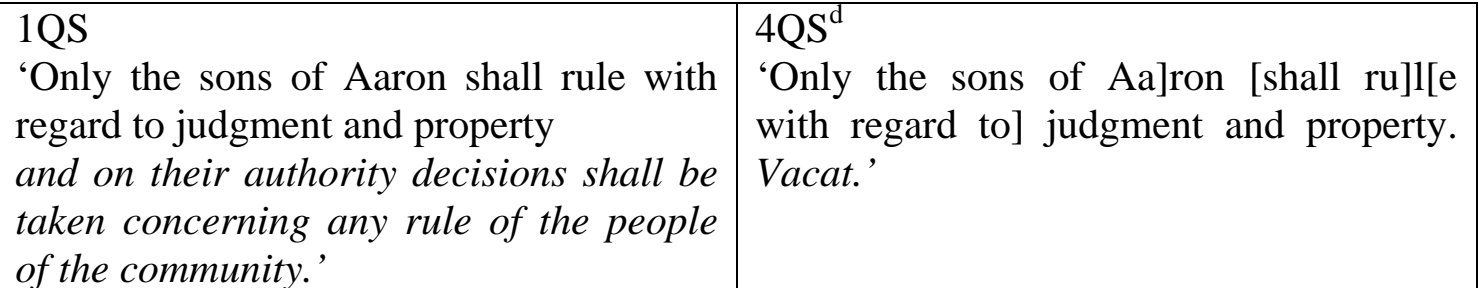

The emphatically placed adverb 'only' seems to imply that there was scope for disagreement in some circles.

In sum, the Community Rule, which in parts of its textual history is well-known for promoting the authority of the sons of Zadok over against 'the many' (esp. the early parts of $1 \mathrm{QS} 5)^{23}$, also contains two important passages where several manuscripts (1QS 5:21 // 4QS ${ }^{\mathrm{d}}$ II:1-2 and 1QS 9:7 // 4QS ${ }^{\mathrm{d}}$ VII:7) favour the sons of Aaron as authority figures in the community. ${ }^{24}$ This is exceedingly interesting in itself and contains, as I tried to argue elsewhere, important clues to the textual development of the $\mathrm{S}$ tradition. ${ }^{25}$ It is instructive, moreover, to reflect on the significant differences in the employment of the terminology 'sons of Aaron' in the Community Rule and the Damascus Document. In the Community Rule the group is clearly priestly but their

\footnotetext{
${ }^{22}$ This passage forms part of the section not attested in $4 \mathrm{QS} \mathrm{e}^{\mathrm{e}}$, cf. P. S. Alexander and G. Vermes, Qumran Cave 4.XIX. Serekh Ha-Yahad and Two Related Texts (DJD 26; Oxford: Clarendon, 1998), 11, 144-149 and Metso, Textual Development, esp. 69-74.

${ }^{23}$ See note 2 above.

${ }^{24}$ Cf. in this context the emphatic statement by Fabry, "Man kommt um die Feststellung nicht herum, dass die ältere Stufe der Gemeinderegel nicht von den Zadokiden spricht!” [emphasis his], "Zadokiden und Aaroniden”, 212.

${ }^{25}$ See Hempel, "Literary Development of the S Tradition”. Fabry also recognizes, "Die fortlaufende Redaktionsgeschichte der S-Literatur zeigt einen Kompetenzgewinn der Zadokiden...,” “Zadokiden und Aaroniden”, 212.
} 
role falls fairly and squarely within the community rather than within a national frame of reference as was the case in the Damascus Document. It seems likely, therefore, that we can observe a certain trajectory in the references to priestly authority in the scrolls beginning with the sons of Aaron in a national/non-community-specific context (D), to the sons of Aaron as priestly authorities within the community (S), to the sons of Zadok as priestly authorities within the community in a different literary stage of S.

4Q286 Berakhot ${ }^{a 26}$

A reference to the sons of Aaron in 4 QBerakhot ${ }^{\mathrm{a}}$ may appropriately be discussed at this juncture because of its notable resemblance to 1QS 9:7. Thus, 4Q286 17b:1-2 seems to refer to the sons of Aaron as figures of authority in matters of judgment and wealth (משפט ובהון). This is an exceedingly interesting and curious piece of evidence because of the obvious terminological overlap with 1QS 9:7 which equally במשפט (singled out 'only the sons of Aaron' as in charge of judgment and wealth ובהוך). The overlap is noted by Bilhah Nitzan, the editor of 4 QBerakhot. ${ }^{27}$ Nitzan relates this statement to "the cultic arrangements of the community for atonement of sins.”28 However, since the language used ('wealth and judgment') occurs frequently in the Community Rule to outline key areas of communal life and fellowship without necessarily implying a cultic context (cf. e.g. 1QS 5:2-3; 5:16; 6:9), this may also be the case in 4Q286. It is just as likely that fragment 17b like fragments 20a,b,13 and 14

\footnotetext{
${ }^{26}$ B. Nitzan, “4QBerakhot”, in Qumran Cave 4. VI. Poetical and Liturgical Texts, Part 1 (ed. E. Eshel et al.; DJD 11; Oxford: Clarendon, 1998), 1-74, esp. 38-39.

${ }^{27}$ Ibidem.

${ }^{28}$ Ibidem, 39.
} 
4Q279 (4QFour Lots; olim 4QTohorot D)

This text was published in DJD 26 as a 'Related Text' to S and may therefore be suitably discussed at this point. ${ }^{30}$ This texts contains a reference to the sons of Aaron in 4Q279 5:4. With reference to this fragment the editors comment, "Frg. 5 seems to be eschatological in content, and to refer to the assignment of rewards ('lots') to the priests, the Levites , the Israelites and the proselytes in the messianic age [...]. If this is the case, then we would very tentatively suggest that 4 Q279 is the remains of a Messianic Rule.”31 The fragment begins with a reference to a written hierarchical

\footnotetext{
${ }^{29}$ On 4Q286 and 4Q288 fragments dealing with reproof, see Nitzan, Qumran Cave 4. VI, 40ff.

${ }^{30}$ See Alexander and Vermes, Qumran Cave 4. XIX, 217-223.

${ }^{31}$ Alexander and Vermes, Qumran Cave 4. XIX, 218.
} 
membership record ("his [f]ellow written down after [him]") familiar from S ( 1QS 5:23; 6:22) and D (cf. CD 13:12; 14:4; 4Q270 7 i 10). The presence of proselytes would bring this scenario closer to D than S, cf. esp. CD 14:4.6 where we also have a fourfold community structure: priests, levites, Israelites and proselytes. ${ }^{32}$ The first and fourth component correspond in the present text and D with the noteworthy difference that 4QFour Lots explicitly uses 'sons of Aaron' rather than more generally 'the priests' as in D. This reference to the sons of Aaron clearly falls within the community-specific realm (note especially the reference to a written record of the hierarchical make-up of the community). However, rather than employing this language to refer to the role of the sons of Aaron as figures of authority the present passage is concerned with the make-up of the community in real or ideological terms. Since they are the first of the four groups referred to here, their preeminent place in the community is nevertheless evident.

4Q265 Miscellaneous Rules olim Serekh Damascus ${ }^{33}$

4Q265 7:3 prohibits priests, who are referred to as belonging to the seed ${ }^{34}$ of Aaron, from sprinkling purifying waters on the sabbath. Apart from the emphasis on the

\footnotetext{
${ }^{32}$ See ibidem, 223 "If our interpretation is correct [...], then the mention of a reward for proselytes in the messianic age is noteworthy.”

${ }^{33}$ For text, translation and commentary see J. M. Baumgarten, Qumran Cave 4. Halakhic Texts (DJD 35; Oxford: Clarendon, 1999), 69-71. See also Hempel, Damascus Texts, 89-104 and L. Doering, Schabbat (TSAJ 78; Tübingen: Mohr Siebeck, 1999), 242-246. For general discussion of the sprinkling ritual see Baumgarten, Qumran Cave 4. 25, 83-87 and idem, "The Red Cow Purification Rites in Qumran Texts”, JJS 46 (1995): 112-119.

${ }^{34}$ On this terminology see García Martínez, “Priestly Functions”, 303.
} 
sabbath, the passage explicitly stresses the priestly prerogative of the sprinkling. ${ }^{35}$ As pointed out by Baumgarten, 4Q274 Tohorot A 2 i 2 attests a further such prohibition in the Qumran corpus. ${ }^{36}$ Moreover, 4Q477 Tohorot $\mathrm{B}^{\mathrm{b}} 1$ ii 5-7 restricts sprinkling anyone defiled with corpse impurity to priests and further prohibits a child from sprinkling the impure. ${ }^{37}$ Baumgarten takes the latter to refer to the level of maturity of the priest. $^{38}$

One of the noteworthy characteristics of 4 Q265 is that it contains a mixture of general halakhic topics alongside clearly community-internal legislation such as the make-up of the council of the community or the penal code. In certain respects such a broad range of material is reminiscent of the Laws of the Damascus Document. In my view the material devoted to the sabbath both in $4 \mathrm{Q} 265$ and in the Damascus Document lacks an explicit basis in the life of the community. ${ }^{39}$ These rules were clearly handed on and cherished in the community, but the context lacks references to sectarian organizational structures. Moreover, the reference to the Temple (4Q265 7:6) points to a wider context. This reference to the priestly rite of sprinkling (or rather not

\footnotetext{
${ }^{35}$ See e.g. Baumgarten, “Red Cow Purification Rites”, 118.

${ }^{36}$ Baumgarten, Qumran Cave 4. 25, 103-105. For a general discussion of issues of purity see ibidem 79-96 and H. K. Harrington, The Purity Texts (Companion to the Qumran Scrolls 5; London: T\&T Clark, 2004).

${ }^{37}$ See Baumgarten, Qumran Cave 4. 25, 116-118. A possible further attestation of such a prohibition is found in 4QD although the crucial word "sprinkle" is restored in both manuscripts (4Q269 8 ii 6 // 4Q271 2:13), see Baumgarten, Qumran Cave 4. 13, 130-132, 173-175 and idem, Qumran Cave 4. 25, 118.

${ }^{38}$ Qumran Cave 4. 25, 82 f and idem, "Red Cow Purification Rites”, 118.

${ }^{39}$ See Hempel, Laws, 15-72 and eadem, Damascus Texts, 96-98, 103-104.
} 
sprinkling on the sabbath) belongs, then, closer to the priestly duties in the noncommunity-specific realm which we witnessed in the Laws of the Damascus Document.

The Rule of the Congregation ${ }^{40}$

Much more within the realm of community-internal affairs are two references to the sons of Aaron as figures of authority in 1QSa 1:16 // 4Q249c pap cryptA Serekh haEdah $^{\text {c41 }}$ line 5 and 1QSa 1:23-24. I have argued elsewhere that the large central section of this text is reminiscent of the communal rules contained in the Damascus Document and was only secondarily associated with the messianic age. ${ }^{42}$ Moreover, an interesting crux in this text, as in the S tradition, is the in my view awkward endorsement of the sons of Zadok as authority figures alongside the sons of Aaron often in the same context, cf. 1QSa 1:2.24; 2:3. Finally, the messianic assembly in the latter part of this text also speaks of the [sons of] Aaron the priests. ${ }^{43}$ It is in any case fairly clear that 1QSa stands much closer to the end of the spectrum that envisages the sons of Aaron as communal leaders - be it in this age or the age to come - rather than

\footnotetext{
${ }^{40}$ On the priestly designations in this text see, e.g., Fabry, “Zadokiden und Aaroniden”; Hempel, "Earthly Essene Nucleus"; L. H. Schiffman, The Eschatological Community of the Dead Sea Scrolls (SBLMS 38; Atlanta: Scholars Press, 1989); H. Stegemann, "Some Remarks to $1 \mathrm{Q} S a$, to $1 \mathrm{QSb}$ and to Qumran Messianism”, RQ 17 (1996): 479-505 and Vermes, “Leadership of the Qumran Community”.

${ }^{41}$ For the edition of the cryptic manuscripts of the Rule of the Congregation see S. Pfann in Qumran Cave 4. 26. Cryptic Texts and Miscellanea, Part 1 (ed. S. Pfann and P. S. Alexander et al.; DJD 36; Oxford: Clarendon, 2000), 513-574, here 551.

42 "Earthly Essene Nucleus”.

${ }^{43}$ Most scholars take 1QS 2:11-21a to describe a messianic event. An exception is Stegemann, "Some Remarks”.
} 
speaking of what one may call their traditional cultic roles in a national context. In sum, the role allocated to the sons of Aaron in 1QSa is reminiscent of the way in which the terminology is used in the Community Rule. This resemblance emerges firstly from their role as community leaders rather than cultic officials. Secondly, 1QSa and S both speak of sons of Aaron and sons of Zadok with both groups vying (literarily in any case) in effect for the same job.

\section{The War Scroll ${ }^{44}$}

Three kinds of references to Aaron occur in the M tradition.

a. Akin to the Damascus Document, esp. the Admonition, the War Scroll contains a number of references to the people of God as comprising the traditional elements 'Israel' and 'Aaron', cf. 1QM 3:12-14 // 4QM ${ }^{\mathrm{f45}}$ 10:4 (the make-up of the people to be written on a banner). A further inscription including the name of the prince of the congregation refers to 'Israel', 'Levi', 'Aaron' and the names of the twelve tribes is prescribed in 1QM 5:1. ${ }^{46}$

\footnotetext{
${ }^{44}$ For a recent edition of the text of M see M. G. Abegg in E. Tov and D. Parry, The Dead Sea Scrolls Reader. 1 Texts Concerned with Religious Law (Leiden: Brill, 2004), 208-243. See also Y. Yadin, The Scroll of the War of the Sons of Light Against the Sons of Darkness (ET B. and C. Rabin; Oxford: OUP, 1962) and J. Duhaime, The War Texts. 1QM and Related Manuscripts (CQS, 6; London: T\&TClark, 2004).

${ }^{45}$ The $4 \mathrm{QM}^{\mathrm{f}}$ recension of the War Scroll is similar to $1 \mathrm{QM}$ though allotting in fragment 10 a more prominent role to the prince of the congregation than is the case in 1QM in the form of two superlinear additions, cf. e.g. Duhaime, War Texts, 22f. See also M. Baillet, Qumrân Cave 4. III (4Q482-4Q520) (DJD 7; Oxford: Clarendon, 1982), 56-68.

${ }^{46}$ According to Yadin, Scroll of the War, 278f. this inscription was to be made on a shield.
} 
b. 1QM 17:2 contains a historical reference to Aaron's sons Nadab, Abihu, Eleazar and Ithamar (cf. Numbers 3).

c. Finally, the scroll allocates a crucial role to the sons of Aaron alongside the levites in guiding the battle, cf. 1QM 7:9-9:9. ${ }^{47}$ A comparable scenario emerges from 4Q493 War Scroll ${ }^{\mathrm{C}} 1-2$, part of a manuscript containing a different recension of the War Scroll from $1 \mathrm{QM} .{ }^{48}$ Both in $1 \mathrm{QM}$ and in $4 \mathrm{QM}^{\mathrm{c}}$ the priests play a leading role in the battle and are identified in the first instance as ‘sons of Aaron’.

It is interesting that this text refers to the priests genealogically explicitly as the sons of Aaron while never employing sons of Zadok language. ${ }^{49}$ This feature aligns the War Scroll with a sizeable group of texts such as MMT, the legal part of D, and curiously also 4QS.

$4 Q M M T^{50}$

4QMMT speaks of the sons of Aaron in two passages while never referring to the sons of Zadok at all. ${ }^{51}$

a. 4QMMT B17 (4Q394 3-7 i 19- ii 1 // 4Q395 1:10-11)

\footnotetext{
${ }^{47}$ For discussion and analysis see Yadin, Scroll of the War, 208-228.

${ }^{48}$ Cf. M. Baillet, Qumrân Grotte 4. III, 49-53, esp. 50 where he identifies this manuscript as evidence of a "recension différente". See also Duhaime, War Texts, 30, 41.

${ }^{49}$ Cf. also Davies, Behind the Essenes, 57; Fabry, “Zadokiden und Aaroniden”, 210 and Vermes, "Leadership of the Qumran Community,” 379.

${ }^{50}$ For the text, introduction and analysis of its various aspects see E. Qimron and J. Strugnell, Qumran Cave 4. 5. Miqsat Ma'aseh Ha-Torah (DJD 10; Oxford: Clarendon, 1994).

${ }^{51}$ So also Fabry, “Zadokiden und Aaroniden”, 209-210.
} 
At the end of a section dealing with the red cow ritual the sons of Aaron are admonished to ensure the proper conduct in cultic matters ("the sons of Aaron are to take care of”). A similar phrase occurs at other junctures, but only here does the text employ the genealogically explicit terminology 'the sons of Aaron' for the priests, cf. B11-12 and B25-27. The priests' role is to ensure proper conduct in cultic matters.

\section{b. B79 (4Q396 1-2 iv 8)}

A second reference to the sons of Aaron occurs in a passage that forbids unsuitable marital unions. Scholars differ as to whether this passage concerns the condemnation of marriages between priests and laity (so Qimron and Himmelfarb ${ }^{52}$ ) or Israelites and foreigners (so Baumgarten, Hayes, and Sharpe ${ }^{53}$ ).

What is of interest for our purposes is the occurrence of sons of Aaron to refer to the priestly component of the people. In short, in MMT akin to the Laws of the Damascus Document the sons of Aaron occur in passages relating to their priestly role in society at large rather than their authoritative status within a community.

\footnotetext{
${ }^{52}$ Qimron and Strugnell, Qumran Cave 4. 5, 171-175 and M. Himmelfarb, "Levi, Phinehas, and the Problem of Intermarriage at the Time of the Maccabean Revolt”, JSQ 6 (1999): 1-24.

${ }^{53}$ Qimron and Strugnell, Qumran Cave 4. 5, 171 n. 178a ; C. Hayes, Gentile Impurities and Jewish Identities. Intermarriage and Conversion from the Bible to the Talmud (Oxford: OUP, 2002), 82-91 and C. J. Sharpe, “Phinean Zeal and Rhetorical Strategy in 4QMMT”, RQ 18 (1997): 207-222.
} 


\section{Temple Scroll}

The picture is rather similar when we turn to the Temple Scroll. Like MMT this text never refers to the sons of Zadok, ${ }^{54}$ and references to the sons of Aaron occur in contexts referring to the cultic role of the priests.

a. $1 \mathrm{Q} 1922: 4-5^{55} / / 11 \mathrm{Q} 205: 25^{56}$ notes the role of the sons of Aaron to sprinkle the sacrificial blood on the altar after the sons of Levi have done the slaughtering. This passage forms part of the 'Festival Calendar', a part of the scrolls that is widely believed to be an originally independent piece inserted after the description of the altar. $^{57}$ The prominent role of the Levites in the Temple Scroll has often been noted. ${ }^{58}$

\footnotetext{
${ }^{54}$ So already Davies, Behind the Essenes, 57 and Fabry, “Zadokiden und Aaroniden”, 209-210.

${ }^{55}$ Cf. Y. Yadin, The Temple Scroll. II. Text and Commentary (Jerusalem: IES, 1983) and E. Qimron,
} The Temple Scroll. A Critical Edition with Extensive Reconstructions (Beer-Sheva/Jerusalem: BenGurion University of the Negev/IES, 1996).

${ }^{56}$ Cf. F. García Martínez, E. J. C. Tigchelaar and A. S. van der Woude, Qumran Cave 11. II. 11Q2-18; 11Q20-31 (DJD 23; Oxford: Clarendon, 1998), 357-409. The word “the priests” is added superlinearly in 11Q20, cf. ibidem 378 and 43.

${ }^{57}$ Cf. S. White Crawford, The Temple Scroll and Related Text (Companion to the Qumran Scrolls 2; Sheffield: Sheffield Academic Press, 2000), 49-57 and earlier literature cited there. Further, F. García Martínez, “Temple Scroll”, in Encyclopedia of the Dead Sea Scrolls (ed. Schiffman and VanderKam), II, 927-933.

${ }^{58}$ Cf. White Crawford, Temple Scroll, 56. See also M. Stone, "Levi”, in Encyclopedia of the Dead Sea Scrolls (ed. Schiffman and VanderKam), I, 485-486 and further literature cited there. Fabry eloquently speaks of the “Archivierung umfangreicher Materialien aus der Levi-Tradition in Qumran,” and asks whether this interest might have been stimulated by a search for the common roots of the two rival priestly traditions, “Zadokiden und Aaroniden”, 213. 
What is of interest for our present purposes is the cultic and non-community-specific part played by the sons of Aaron in this passage.

b.11Q19 34:13-14 ${ }^{59}$ refers to the sons of Aaron's role of burning the sacrifices upon the altar and forms part of the description of the inner court of the Temple, especially the slaughter house. ${ }^{60}$

c. A third reference to the sons of Aaron occurs in the context of the allocation of storerooms in 11Q19 44:5. ${ }^{61}$

In sum, the Temple Scroll falls clearly within the large group of texts that employ sons of Aaron terminology in a non-community-specific sense emphasizing their traditional cultic duties. Again, this text never employs sons of Zadok language.

4Q174 Florilegium ${ }^{62}$

4Q174 5:2 ${ }^{63}$ contains a reference to Israel and Aaron in a fragmentary context. Brooke suggests that we have here the remains of a reference to the expected messiah

\footnotetext{
${ }^{59}$ Cf. Yadin, Temple Scroll, II, 147.

${ }^{60}$ See White Crawford, Temple Scroll, 36-38.

${ }^{61}$ Cf. Yadin, Temple Scroll, II, $185 f$.

${ }^{62}$ Cf. J. M. Allegro with A. A. Anderson, Qumran Cave 4. I (4Q158-4Q186) (DJDJ 5; Oxford, Clarendon, 1968), 53-57. See also J. Strugnell, “Notes en marge du volume V des 'Discoveries in the Judaean Desert of Jordan’”, RQ 7 (1970): 163-276, esp. 220-225.

${ }^{63}$ Reconstructed by Steudel to occur at 4Q174 IV:7, see Der Midrasch zur Eschatologie aus der Qumrangemeinde (4QMidrEschat ${ }^{a . b}$ ) (STDJ 13; Leiden: Brill, 1994), 26, 32.
} 
of Israel and Aaron. ${ }^{64}$ This interpretation has been questioned by Steudel who thinks of a phrase 'Israel and Aaron' to describe the make-up of the community as attested, e.g., also in CD $1 .{ }^{65}$ Also reminiscent of $\mathrm{D}$ and $\mathrm{S}$ is the reference to the sons of Zadok in 4 Q174 1-2 i $17^{66}$ in a passage interpreting Ezek 37:23. ${ }^{67}$ We saw above that Ezek 44 was interpreted in the Damascus Document (cf. CD 3:20-4:4) with reference to various phases in the community's emergence. 4QFlorilegium is thus closely aligned with those texts that speak of the make-up of the community both in terms of 'Israel and Aaron' and in terms of the sons of Zadok, the latter inspired by Ezekiel, in particular the Admonition of the Damascus Document.

4Q390 Apocryphon of Jeremiah $C^{e}$ 4Q390 is one of six manuscripts of 4QApocryphon Jeremiah C published by Devorah Dimant. $^{68}$ One of the characteristic features identified by Dimant is that the composition seems to speak of events known from the scriptures in the past tense, whereas non-scriptural Second Temple period events and the eschatological period are referred to in the future tense, as is the case in the passage to be considered below. Dimant proposes a revelation received by Jeremiah as the most likely 'narrative context' of the composition ${ }^{69}$ and suggests that the composition is best understood as

\footnotetext{
${ }^{64}$ G. J. Brooke, Exegesis at Qumran. 4QFlorilegium in its Jewish Context (JSOTSup 29; Sheffield: Sheffield Academic Press, 1985), 160f.

${ }^{65}$ See Steudel, Midrasch zur Eschatologie, 49.

${ }^{66}$ Reconstructed by Steudel to occur at 4Q174 III:17, see Midrasch zur Eschatologie, 25, 31-32.

${ }^{67}$ Cf. e.g. Knibb, Qumran Community, 261 and Steudel, Midrasch zur Eschatologie, 32.

${ }^{68}$ See D. Dimant, Qumran Cave 4. XXI. Parabiblical Texts, Part 4: Pseudo-Prophetic Texts (DJD 30; Oxford: Clarendon, 2001).

${ }^{69}$ Cf. Qumran Cave 4. XXI, 97f, 100, 243.
} 
'an apocalypse'. ${ }^{70}$ As far as the provenance of the work is concerned Dimant proposes to consider the Apocryphon as "a type of intermediate category, related, but not identical, to the sectarian literature” and comparable to Jubilees and the Temple Scroll in this regard. ${ }^{71}$

The fragmentary passage that is of immediate relevance for our present enquiry occurs in 4Q390 1:2-3 and forms part of an historical overview of the Second Temple period. $^{72}$ The period is presented in deuteronomistic style as a cycle of wrongdoing and punishment referring to a seventy year period of priestly rule. ${ }^{73}$ The present passage belongs with those parts of the scriptures and the scrolls that speak of the sons of Aaron as the legitimate, God-given priesthood. Moreover the preserved text clearly refers to their leading role over Israel. The present passage is fragmentary, and it is somewhat ambiguous whether or not the sons of Aaron or the Israelites are here the subject of polemic. ${ }^{74}$ A critical attitude towards the priests is a feature that characterizes other parts of this composition. ${ }^{75}$ Whatever the case may be, this text clearly offers a further attestation of the sons of Aaron in what appears to be a national (non-community-specific) context.

4Q513 Ordinances ${ }^{b 76}$

\footnotetext{
${ }^{70}$ Ibidem, 100.

${ }^{71}$ Ibidem, 112.

${ }^{72}$ Ibidem, 237-244.

${ }^{73}$ Ibidem, 97, 237f.

${ }^{74}$ Ibidem, 239.

${ }^{75}$ Ibidem, 112, 116.

${ }^{76}$ See Baillet, Qumrân Cave 4. III, 287-295, esp. 291 and Plate LXXII.
} 
4Q513 10 ii 8 mentions the sons of Aaron in a fragmentary context. The preceding lines speak of the sanctuary and purity, the issue of mixing and the children of Israel. The context in this particular fragment and in the text as a whole is clearly national and cultic.

The remaining references to Aaron in the scrolls occur in historical, scriptural, and exegetical contexts and will not need to be considered here. ${ }^{77}$

\section{Conclusion}

In sum, I hope to have shown that the priestly terminology in the scrolls, especially the terms sons of Aaron and sons of Zadok, do not appear to be employed entirely randomly and synonymously. Rather, a line of development appears to have left its mark on the literature.

a. We have a sizeable group of texts that speak of the sons of Aaron in a noncommunity-specific, national context. These text usually emphasize the cultic duties of the sons of Aaron ${ }^{78}$ and do not refer to the sons of Zadok at all.

\footnotetext{
${ }^{77}$ Nor will the remaining isolated reference to the sons of Aaron in a text classified as "noncaractérisé” (i.e. 5Q20 1:2) shed much light, see J. T. Milik in M. Baillet, J. T. Milik and R. de Vaux, Les "Petites Grottes" de Qumrân. Exploration de la falaise. Les grottes 2Q, 3Q, 5Q, 6Q, 7Q à 10Q. Le rouleau de cuivre (DJDJ 3; Oxford: Clarendon, 1962), 193-197.

${ }^{78}$ Fabry already pointed in a similar direction when he observes the exclusively liturgical functions and actions of the sons of Aaron in the Temple Scroll, MMT and M, see "Zadokiden und Aaroniden”, 211. Earlier still Liver had rightly highlighted the way in which the sons of Zadok are allocated "primarily not cultic but didactic functions" and "the lack of allusion to any ritual function of the sons of Zadok the priests in these prefatory phrases is ample evidence that their unique place among the priesthood as a whole, lay not in the cultic sphere.," "Sons of Zadok the Priests”, 6, see also 28-30.
} 
b. A second group of texts speak of the sons of Aaron with reference to the make-up of the community, in particular its priestly (versus lay) component. Sons of Aaron is never used to refer to the community as a whole as is the case with the sons of Zadok in CD 3-4. ${ }^{79}$

c. A third group of texts refers to Aaron to describe the priestly messiah who is expected alongside a lay or royal messiah.

d. Finally, the sons of Aaron appear as authority figures alongside the sons of Zadok in a number of community-specific texts, esp. the Community Rule and 1QSa. In this context we emphasized the important witness of one element of the tradition that employs sons of Aaron terminology in a community-specific context to the exclusion of the sons of Zadok in several manuscripts, see esp. 1QS 5:21 // 4QS ${ }^{\mathrm{d}}$ II:1-2 and 1QS 9:7 // 4QS ${ }^{\mathrm{d}}$ VII:7. This shared element of common ground between $1 \mathrm{QS}$ and $4 \mathrm{QS}$ seems to me to come from an early period in the growth of the S tradition.

The view that the Zadokites played a key role at the very beginning of the community's existence and that matters of priestly descent were crucial in the events that lead to the parting of the ways has gradually been losing ground. ${ }^{80}$ The results of the above survey and the profile that can be derived from it also speak rather in favour of the sons of Aaron as the earlier strand in the scrolls even in community-specific

\footnotetext{
${ }^{79}$ Pace Anderson, "Aaron”, 2, who claims "Aaron and Zadok function as ciphers for the sect as a whole.”

${ }^{80}$ See, e.g., Kugler, "Priesthood at Qumran”, 97-100 and J. J. Collins, “The Origin of the Qumran Community: A Review of the Evidence”, in To Touch the Text. Biblical and Related Studies in Honor of Joseph A. Fitzmyer, S.J. (ed. M. P. Horgan and P. J. Kobleski; New York: Crossroad, 1989), 159178.
} 
contexts. ${ }^{81}$ Morevoer, we noted that a number of passages dealing with the earliest forms of communal life lack interest in the geneological background of the priestly leadership altogether (cf. 1QS 6:2-4 and 1QS 8:1). ${ }^{82}$

There has been a considerable amount of scholarly interest in the equally complex portrayal of the sons of Aaron in the Hebrew Bible. ${ }^{83}$ I am particularly intrigued by the way in which the evidence of the scrolls, which goes back to a later period, seems to mirror the complexity of the Hebrew Bible. The impression one gets is that the developments that left their mark on the Bible are coming around in further waves in writings of a later time. ${ }^{84}$ I hope to have shown that despite the complexity of the evidence a certain trajectory can be traced based on the use of sons of Aaron terminology across a varied spectrum of non-biblical texts from the corpus of the scrolls.

${ }^{81}$ Here my own conclusions differ significantly from those reached by Kugler, "Priesthood at Qumran”, 101.

${ }^{82}$ Cf. Hempel, “Diversity and Identity in the S-Tradition”.

${ }^{83}$ See, e.g., J. Blenkinsopp, “The Judaean Priesthood during the Neo-Babylonian and Achaemenid Periods: A Hypothetical Reconstruction”, CBQ 60 (1998): 25-43; idem, “Bethel in the Neo-Babylonian Period” and G. N. Knoppers, “The Relationship of the Priestly Genealogies to the History of the High Priesthood in Jerusalem,” in Judah and the Judeans in the Neo-Babylonian Period (ed. O. Lipschits and J. Blenkinsopp; Winona Lake: Eisenbrauns, 2003), 93-107 and 109-133 and further literature cited there. Further, G. Nickelsburg, “Aaron”, in Reallexikon für Antike und Christentum Supplement-Band I, Stuttgart: Hiersemann, 2001, cols. 1-11.

${ }^{84}$ In Fabry’s view the post-exilic rivalries simply continued up to a much later period, “Die Konflikte in der nachexilischen Priesterschaft blieben bestehen und wirkten sich offensichtlich bis ins 1.Jh. v.Chr., möglicherweise sogar bis in neutestamentliche Zeit hinein aus.” see "Zadokiden und Aaroniden”, 215. 
Charlotte Hempel, University of Birmingham, UK 